\title{
PHYTOCHEMICAL COMPOSITION AND TOXICITY OF STINGLESS BEE PROPOLIS FROM VARIOUS PROVINCES IN INDONESIA
}

\author{
MAHANI MAHANI ${ }^{1 *}$, JAFAR SYIDIK ${ }^{1}$, ZAIDA ZAIDA ${ }^{1}$, AHMAD SULAEMAN $^{2}$, HARDINSYAH HARDINSYAH ${ }^{2}$, \\ NUNUNG NURJANAH ${ }^{3}$
}

${ }^{1}$ Department of Food Technology, Faculty of Agricultural Industrial Technology, Padjadjaran University, West Java, Indonesia. ${ }^{2}$ Department of Community Nutrition, Faculty of Human Ecology, IPB University, West Java, Indonesia. ${ }^{3}$ National Institute of Health Research and Development, Indonesian Ministry of Health, West Java, Indonesia. Email: mahani2018@unpad.ac.id

\author{
Received: 12 February 2021, Revised and Accepted: 26 March 2021
}

ABSTRACT

Objective: The main objectives of the research are to determine the phytochemical content and toxicity of stingless bee propolis from various provinces in Indonesia.

Methods: Phytochemical testing of alkaloids and triterpenoids on propolis used a qualitative method, while for testing phenolics, flavonoids, and tannins using quantitative methods. Then, to test the toxicity of stingless bee propolis using the Brine Shrimp Lethality Test method.

Results: Propolis with the highest alkaloid and triterpenoid content is Central Java propolis from Tetragonula laeviceps species. Then, propolis with the highest total flavonoid content is South Sulawesi propolis of Tetragonula biroi species. Propolis with the highest total tannin content and total phenolic content is South Sulawesi propolis from Geniotrigona incise species. Propolis with the highest toxicity is Banten propolis from T. laeviceps species.

Conclusion: Stingless bee propolis from various provinces in Indonesia contains various phytochemicals and toxicities. Furthermore, there is a strong correlation between total flavonoid content and propolis toxicity.

Keywords: Propolis, Stingless bees, Phytochemicals, Toxicity, Resin plant.

(c) 2021 The Authors. Published by Innovare Academic Sciences Pvt Ltd. This is an open access article under the CC BY license (http://creativecommons.org/ licenses/by/4.0/) DOI: http://dx.doi.org/10.22159/ajpcr.2021v14i5.41116. Journal homepage: https://innovareacademics.in/journals/index.php/ajpcr

\section{INTRODUCTION}

Propolis is a substance derived from plant resins collected by bees and mixed with enzymes found in bee salivary glands and is commonly used to protect the hive [1,2]. Stingless bee propolis has several advantages, such as a higher yield, and the phytochemical composition is more diverse [3].

The geographical location affects the composition of propolis produced [4,5]. The different geographic locations allow there to be different species of bees and plant origin sources. According to Cauich-Kumul and Segura [6], propolis in different locations can contain different phytochemicals. Araújo et al. and Mahani et al. [7,8] reported that differences in the composition of active compounds or phytochemicals in propolis could affect propolis toxicity. The objective of this study was to determine the phytochemical content and toxicity of propolis.

\section{MATERIALS AND METHODS}

\section{Materials}

Stingless bee propolis from ten provinces in Indonesia. The selection of provinces is based on the availability of stingless bee cultivators. The parameters tested included the phytochemical content of alkaloids, triterpenoids, total phenolics, total flavonoids, total tannins, and propolis toxicity.

\section{Identification of bee species and plant origin source}

The stingless bee species data were obtained using survey and examination using a microscope and camera, then compared with a key book. Then, the plant origin source's identification base on observations where the bees routinely perched on the plant to collect the resin. Identification carried out on 15 primary plants around the colony.

\section{Alkaloid compound screening}

The sample was made alkaline with ammonia added, then added chloroform. The chloroform layer is taken with a pipette, and then adds $2 \mathrm{~N}$ hydrochloric acid. The mixture was shaken strong that there are two layers. The acid layer is taken with a pipette and then divided into three parts. Each tube was added with different reagents, namely, Dragendorff reagent and Mayer reagent. Alkaloid compounds were identified as positive if an orange precipitate was formed after being given Dragendorff's reagent, a white precipitate with Mayer's reagent [9].

\section{Triterpenoid compound screening}

The sample was added ether. Poured into the vaporizer cup and allow it to evaporate until dry. Furthermore, the reagent is added LiebermannBurchard. The occurrence of purple color indicates the presence of triterpenoids compounds whereas the blue-green color indicates steroid compounds [9].

\section{Total flavonoid content (TFC)}

TFC of each honey sample was determined according to the method was reported by Khalil et al. [10] with minor modification. Briefly, honey $0.20 \mathrm{~g}$ was mixed with $4 \mathrm{ml}$ of distilled water. At baseline, $0.3 \mathrm{ml}$ of sodium nitrite $(5 \%, \mathrm{w} / \mathrm{v})$ were added. After $5 \mathrm{~min}, 0.6 \mathrm{ml}$ aluminum chloride $(10 \% \mathrm{w} / \mathrm{v})$ was added, followed by the addition of $2 \mathrm{~mL}$ of sodium hydroxide (1 M) 5 min later. Immediately after that, the volume was increased to $10 \mathrm{~mL}$ by the addition of $2.4 \mathrm{ml}$ distilled water. The mixture was vigorously shaken to ensure adequate mixing, and the absorbance was read at $510 \mathrm{~nm}$.

\section{Total phenolic content (TPC)}

TPC was measured using the method described by Alotibi et al. [11]. Briefly, honey about $0.2 \mathrm{~g}$ and added $0.5 \mathrm{ml}$ of Folin-Ciocalteu reagent and added $7.5 \mathrm{ml}$ aquabidest. Then, the blend was allowed for $10 \mathrm{~min}$ at 
room temperature and then $1.5 \mathrm{ml}$ of $20 \%$ sodium carbonate was added. Aquabidest was added up to volume $10 \mathrm{ml}$. The blended was heated in the water bath at temperature $40^{\circ} \mathrm{C}$ for $20 \mathrm{~min}$ and immediately after that was cooled quickly using ice and allowed to react for $30 \mathrm{~min}$. The absorbance was measured at $760 \mathrm{~nm}$.

\section{Total tannin content (TTC)}

$0.5 \mathrm{~g}$ of sample is dissolved with aqua bidest up to $10 \mathrm{ml}$. Then as much as $1.0 \mathrm{ml}$ of the sample is piped and put into a $10 \mathrm{ml}$ container that already contains $7.5 \mathrm{ml}$ of aqua bidest. Then add $0.5 \mathrm{ml}$ of FolinCiocalteu reagent. Let stand for $3 \mathrm{~min}$, and then add $1.0 \mathrm{ml}$ of saturated $\mathrm{Na}_{2} \mathrm{CO}_{3}$ solution. Incubate the solution for $15 \mathrm{~min}$, and then read the absorption at the maximum wavelength. Calculated using the standard curve has been obtained so that the concentration of the sample being measured is known [12].

\section{Toxicity test (brine shrimp lethality test [BSLT] method)}

We used preliminary toxicity of BSLT using Artemia Salina Leach [13]. The Artemia cysts were hatched in the laboratory using artificial seawater at $27-30^{\circ} \mathrm{C}$ medium. Appropriate light, $\mathrm{pH}$ of $7.5-8.5$, alkaline water with a salinity of $3 \%$, and temperature of $27-30^{\circ} \mathrm{C}$ were regulated during the test. The larvae were collected from hatcheries with a plastic pipette for the $\mathrm{LC}_{50}$ study. $\mathrm{LC}_{50}$ was estimated in five dilutions $(250,500,750,1000$, and $1500 \mu \mathrm{g} / \mathrm{ml})$ of propolis extracts for $24 \mathrm{~h}$. In each plate, $0.5 \mathrm{ml}$ of propolis extract with different concentrations was added to $4.5 \mathrm{ml}$ of the brine shrimp solution. Ten brine shrimp larvae that had been grown for $48 \mathrm{~h}$ were added to each plate. For each propolis concentration, one DMSO with $4.5 \mathrm{ml}$ of brine shrimp solution without propolis extract was used as a control. The plates were sealed with their lids in the darkness at room temperature for $24 \mathrm{~h}$. During the test, feeding and aeration were not allowed. After $24 \mathrm{~h}$, the number of dead and surviving larvae was counted on the plates, and the samples' cytotoxicity was then determined. Each experiment was performed in triplicate. During each experiment, if the control group's mortality was more than $10 \%$ of the experiment group, the procedure must be repeated. The mortality was calculated using the following formula:

$$
\text { Mortality }=\frac{\text { Accumulation of death larvae }}{\text { Accumulation of death }+ \text { surviving larvae }} \times 100 \%
$$

The graph was constructed with log concentration as the X-axis and mortality as the Y-axis. A substance was confirmed as toxic when $\mathrm{LC}_{50}$ of the extract was $<1000 \mathrm{ppm}$, and $\mathrm{LC}_{50}$ of the pure compound was $<30$ ppm.

\section{Statistical analysis}

The correlation between total phytochemicals content and propolis toxicity test using the Spearman correlation test with SPSS software help. The statistical significance was accepted if $\mathrm{p}<0.01$.

Table 1: Stingless bee species in various provinces in Indonesia

\begin{tabular}{|c|c|}
\hline Province & Stingless bee species \\
\hline South Kalimantan & $\begin{array}{l}\text { Heterotrigona itama } \\
\text { Tetragonula laeviceps } \\
\text { Geniotrigona thoracica }\end{array}$ \\
\hline North Sumatra & $\begin{array}{l}\text { Tetragonula minangkabau } \\
\text { Sundatrigona moorei }\end{array}$ \\
\hline South Sulawesi & $\begin{array}{l}\text { Tetragonula biroi } \\
\text { Geniotrigona incisa }\end{array}$ \\
\hline Banten & Tetragonula laeviceps \\
\hline West Java & Tetragonula laeviceps \\
\hline Central Java & Tetragonula laeviceps \\
\hline West Kalimantan & Heterotrigona itama \\
\hline East Kalimantan & Heterotrigona itama \\
\hline West Nusa Tenggara & Tetragonula fuscobalteata \\
\hline Maluku & Tetragonula fuscobalteata \\
\hline
\end{tabular}

\section{RESULTS}

\section{Identification of bee species}

Based on Table 1, the most widely cultivated bee species is Tetragonula laeviceps. This species found in four different provinces, namely, Banten, West Java, Central Java, and South Kalimantan. South Kalimantan has the most diverse stingless bees than other provinces with three species then followed by North Sumatra and South Sulawesi with two species of stingless bees. Meanwhile, in other provinces, there are only one stingless bee species that cultivate.

\section{Plant origin source}

As shown in Table 2, there are 31 types of resin source plants in ten provinces in Indonesia. The most widely distributed plant and used as a source of resin is mango. Mango plants spread across nine provinces, namely, North Sumatra, Banten, West Java, Central Java, South Kalimantan, East Kalimantan, South Sulawesi, West Nusa Tenggara, and Maluku.

\section{Phytochemical propolis}

Phytochemical screening tests showed that the propolis with the highest alkaloid and triterpenoid content is Central Java propolis from T. laeviceps species (Table 3). The quantitative phytochemical test shows that TFC of propolis ranges from $0.005 \%$ to $0.442 \%$. Then, for the TPC in propolis in the range of $0.254-1.897 \%$, while the TTC of propolis is in the range of $0.023-0.957 \%$ (Table 4 ).

\section{Propolis toxicity}

The propolis with the highest toxicity was Banten propolis, which came from the T. laeviceps species (Table 5). This propolis has an $\mathrm{LC}_{50}$ value of $<50$ and gets into a highly toxic category. Another propolis included in the highly toxic category is North Sumatra propolis originating from the Sundatrigona moorei species with an $\mathrm{LC}_{50}$ value of 55.09. The smaller the $\mathrm{LC}_{50}$ value, the more toxic the propolis will be.

Correlation between phytochemical content (TFC, TPC, and TTC) and propolis toxicity

Based on the Spearman correlation test, the significance value between TTC and propolis toxicity was 0.692 . This value indicates that the two variables do not have a significant correlation. Then, the significance value obtained between the TPC and propolis's toxicity is 0.350 . This value indicates that the two variables do not have a significant correlation.

The resulting significance value between the TFC and propolis toxicity is 0.009 . This value indicates that the two variables have a significant correlation. Besides, it is also known that the correlation coefficient value of the two variables is 0.667 . This means that the two variables have a strong correlation (Table 6). Then, a positive value on the correlation coefficient means that these two variables have a unidirectional correlation. Thus, the higher the TFC of propolis, the higher the $\mathrm{LC}_{50}$ value of propolis. In other words, the toxicity is getting lower

\section{DISCUSSION}

The diversity of bee species in various provinces can affect the characteristics of the propolis produced. The diversity of propolis in Indonesia is influenced by differences in resin source plant and bee species [3]. Even so, there is no evidence that enzymes in bees can carry out chemical changes in compounds extracted from plants and used for propolis production [14]. Therefore, it can say that the bee species affect the characteristics of the propolis produced but indirectly because different bee species will tend to take resin sources for propolis from different plants. This statement is supported by Rasmussen and Cameron [15] who revealed that each species of bee has unique behavior and is not the same as other bee species. Furthermore, stingless bees choose plants that they use as a source of resin based on the distance between flowers and nests, aroma, and flower color [16]. According to Fawzy and Al-Deeb [17], different types of resin plants can cause different phytochemical content of propolis and affect the biological activity of the propolis produced. So from that, it can be said that if the bee species has an indirect effect, while the type of resin source plant directly affects the characteristics of the propolis produced. 
Table 2: Plants origin in various provinces in Indonesia

\begin{tabular}{|c|c|c|c|c|c|c|c|c|c|c|}
\hline Plant & NS & B & WJ & EJ & WK & EK & SK & SS & WNT & M \\
\hline Acacia (Acacia mangium) & & $*$ & * & $*$ & $*$ & & & & & \\
\hline Avocado (Persea americana) & & & $*$ & & & & & & & \\
\hline Cempaka (Magnolia champaca) & & & & & & & & $*$ & & \\
\hline Cempedak (Artocarpus integer) & & & & & & * & & & * & \\
\hline Dadap (Erythrina variegata) & & & & & & & & & & $*$ \\
\hline Damar (Agathis dammara) & * & & & & & & & * & & \\
\hline Durian (Durio zibethinus) & $*$ & $*$ & & $*$ & & $*$ & $*$ & $*$ & $*$ & \\
\hline Jengkol (Archidendron pauciflorum) & & & $*$ & & & & & & & \\
\hline Pomelo (Citrus maxima) & & & & & & & & & * & \\
\hline Lemon (Citrus limon) & & & $*$ & & & & & & & \\
\hline Kaju Londong (Diospyros celebica) & & & & & & & & $*$ & & \\
\hline Cacao (Theobroma cacao) & * & & & & & & & * & & \\
\hline Rubber (Hevea brasiliensis) & & & & & $*$ & $*$ & & & & \\
\hline Kuweni (Mangifera odorata) & $*$ & & & & & & & & & \\
\hline Mahogany (Swietenia mahagoni) & & $*$ & & $*$ & & & & & & \\
\hline Jackfruit (Artocarpus heterophyllus) & $*$ & $*$ & $*$ & $*$ & & * & * & & $*$ & * \\
\hline Palli (Lithocarpus sundaicus) & & & & & & & & $*$ & & \\
\hline Petai (Parkia speciosa) & * & $*$ & & & & & * & & & \\
\hline Pine (Pinus merkusii) & & & & & & & & $*$ & & \\
\hline Banana (Musa acuminata) & $*$ & $*$ & $*$ & $*$ & & & & & * & $*$ \\
\hline Poringan (Codiaeum variegatum) & & & & & & & & $*$ & & \\
\hline Randu (Ceiba pentandra) & & & & & & * & & * & & \\
\hline Rengas (Gluta renghas) & & & & & * & & & & & \\
\hline Resak Air (Vatica pauciflora) & & & & & * & & & & & \\
\hline Sempur (Dillenia indica) & & & & & * & & & $*$ & & \\
\hline Rubber cassava (Manihot Glaziovii) & & & & & & & & $*$ & $*$ & $*$ \\
\hline Soursop (Annona muricata) & & $*$ & & $*$ & & & & & & \\
\hline Temau (Curcuma zedoaria) & & & & & $*$ & & & & & \\
\hline
\end{tabular}

NS: North Sumatra, B: Banten WJ: West Java, CJ: Central Java, WK: West Kalimantan, EK: East Kalimantan, SK: South Kalimantan, SS: South Sulawesi, WNT: West Nusa Tenggara, M: Maluku

Table 3: Results of screening for alkaloids and triterpenoids from Indonesian stingless bee propolis

\begin{tabular}{llll}
\hline Province & Bee Species & Alkaloid & Triterpenoid \\
\hline North Sumatra & Tetragonula & + & + \\
& minangkabau & & \\
North Sumatra & Sundatrigona moorei & ++ & ++ \\
Banten & Tetragonula laeviceps & +++++ & +++ \\
West Java & Tetragonula laeviceps & ++ & ++ \\
Central Java & Tetragonula laeviceps & ++++++ & +++++ \\
West Kalimantan & Heterotrigona itama & ++++ & + \\
East Kalimantan & Heterotrigona itama & +++ & ++ \\
South Kalimantan & Heterotrigona itama & + & + \\
South Kalimantan & Tetragonula laeviceps & +++ & +++ \\
South Kalimantan & Geniotrigona & +++ & +++ \\
& thorasica & & \\
South Sulawesi & Geniotrigona incisa & +++ & +++ \\
South Sulawesi & Tetragonula biroi & + & +++ \\
West Nusa & Tetragonula & ++ & ++ \\
Tenggara & fuscobalteata & & \\
Maluku & Tetragonula & ++ & ++ \\
& fuscobalteata & & \\
\hline
\end{tabular}

One of the characteristics of propolis being tested is its phytochemical content. Propolis, which contains the highest alkaloid compounds, is found in Central Java propolis from the bee T. Laeviceps. The plant source of the resin influences the high alkaloid content in propolis. Central Java Province has seven types of resin source plants, six of which contain alkaloid compounds, including acacia, mahogany, mango, jackfruit, banana, and soursop. The alkaloid compounds in propolis have properties as antibacterial, anticancer, and analgesic [18]. The propolis with the highest triterpenoid content found in Central Java propolis comes from the bee T. Laeviceps. Central
Table 4: TFC, TPC and TTC from Indonesian stingless bee propolis

\begin{tabular}{|c|c|c|c|c|}
\hline Province & Bee species & TFC \% & TPC \% & TTC \% \\
\hline North Sumatra & $\begin{array}{l}\text { Tetragonula } \\
\text { minangkabau }\end{array}$ & 0.024 & 0.254 & 0.023 \\
\hline North Sumatra & Sundatrigona moorei & 0.005 & 1.237 & 0.449 \\
\hline Banten & Tetragonula laeviceps & 0.047 & 0.665 & 0.455 \\
\hline West Java & Tetragonula laeviceps & 0.015 & 0.377 & 0.130 \\
\hline Central Java & Tetragonula laeviceps & 0.065 & 0.558 & 0.213 \\
\hline West Kalimantan & Heterotrigona itama & 0.011 & 0.686 & 0.303 \\
\hline East Kalimantan & Heterotrigona itama & 0.005 & 0.335 & 0.025 \\
\hline South Kalimantan & Heterotrigona itama & 0.015 & 0.279 & 0.085 \\
\hline South Kalimantan & Tetragonula laeviceps & 0.115 & 0.375 & 0.158 \\
\hline South Kalimantan & Geniotrigona thorasica & 0.184 & 0.637 & 0.221 \\
\hline South Sulawesi & Geniotrigona incisa & 0.061 & 1.897 & 0.957 \\
\hline South Sulawesi & Tetragonula biroi & 0.442 & 0.743 & 0.444 \\
\hline West Nusa & Tetragonula & 0.048 & 1.103 & 0.338 \\
\hline & fuscobalteata & & & \\
\hline Maluku & $\begin{array}{l}\text { Tetragonula } \\
\text { fuscobalteata }\end{array}$ & 0.089 & 0.749 & 0.305 \\
\hline
\end{tabular}

TFC: Total flavonoid content, TPC: Total phenolic content, TTC: Total tannin content

Java has seven types of resin source plants, five of which are plants containing triterpenoids. These plants include acacia, durian, jackfruit, banana, and soursop. Triterpenoid compounds are known to have antituberculosis activity [19].

The propolis with the highest TFC was South Sulawesi propolis, which came from Tetragonula biroi. The TFC in propolis is $0.442 \%$. TFC of propolis is influenced by the type of plant that is used as a source of propolis resin by bees [20]. There are nine types of resin source plants in South Sulawesi that contain flavonoids, including durian, mango, 
Table 5: The toxicity of Indonesian stingless bee propolis

\begin{tabular}{|c|c|c|c|}
\hline Province & Bee species & $\begin{array}{l}\text { Toxicity } \\
\text { LC }_{50} \text { (ppm) }\end{array}$ & Note \\
\hline Banten & $\begin{array}{l}\text { Tetragonula } \\
\text { laeviceps }\end{array}$ & $<50.00$ & Highly toxic \\
\hline North Sumatra & $\begin{array}{l}\text { Sundatrigona } \\
\text { moorei }\end{array}$ & 55.09 & Highly toxic \\
\hline South Kalimantan & $\begin{array}{l}\text { Heterotrigona } \\
\text { itama }\end{array}$ & 270.60 & Moderately toxic \\
\hline East Kalimantan & $\begin{array}{l}\text { Heterotrigona } \\
\text { itama }\end{array}$ & 451.32 & Moderately toxic \\
\hline West Java & $\begin{array}{l}\text { Tetragonula } \\
\text { laeviceps }\end{array}$ & 521.74 & Moderately toxic \\
\hline Central Java & $\begin{array}{l}\text { Tetragonula } \\
\text { laeviceps }\end{array}$ & 615.84 & Moderately toxic \\
\hline North Sumatra & $\begin{array}{l}\text { Tetragonula } \\
\text { minangkabau }\end{array}$ & 621.49 & Moderately toxic \\
\hline West Nusa & Tetragonula & 624.34 & Moderately toxic \\
\hline $\begin{array}{l}\text { Tenggara } \\
\text { South Sulawesi }\end{array}$ & $\begin{array}{l}\text { fuscobalteata } \\
\text { Tetragnula biroi }\end{array}$ & 656.41 & Moderately toxic \\
\hline West Kalimantan & $\begin{array}{l}\text { Heterotrigona } \\
\text { itama }\end{array}$ & 802.26 & Moderately toxic \\
\hline South Kalimantan & $\begin{array}{l}\text { Tetragonula } \\
\text { laeviceps }\end{array}$ & 838.05 & Moderately toxic \\
\hline South Sulawesi & $\begin{array}{l}\text { Geniotrigona } \\
\text { incisa }\end{array}$ & 854.75 & Moderately toxic \\
\hline Maluku & $\begin{array}{l}\text { Tetragonula } \\
\text { fuscobalteata }\end{array}$ & 932.63 & Moderately toxic \\
\hline South Kalimantan & $\begin{array}{l}\text { Geniotrigona } \\
\text { thoracica }\end{array}$ & $>1000.00$ & Slightly toxic \\
\hline
\end{tabular}

Table 6: Correlation (spearman correlation test) between phytochemical content (TFC, TPC, TTC) and propolis toxicity

\begin{tabular}{llll}
\hline Toksisitas $\left(\mathbf{L C}_{50}\right.$ ) & TFC & TTC & TPC \\
\hline Correlation Coefficient & $0.667^{* *}$ & 0.116 & 0.270 \\
Sig. (two-tailed) & 0.009 & 0.692 & 0.350 \\
\hline
\end{tabular}

**Correlation is significant at the 0.01 level (two-tailed), TFC: Total flavonoid content, TPC: Total phenolic content, TTC: Total tannin content

cempaka, damar, cocoa, pine, randu, resak, and rubber cassava. The TFC of propolis is related to their ability as an antioxidant. This is supported by research, which states a positive correlation between Brazilian propolis's TFC and its antioxidant activity [21]. Another study also shows the same thing in the Spanish propolis sample [22].

The propolis with the highest TPC was South Sulawesi propolis from the Geniotrigona incisa species with a value of $1.9 \%$. The TPC in propolis is related to its ability as an antioxidant. Based on research, TPC of propolis has a positive correlation with its antioxidant activity [23]. This is also following Alfaridz and Amalia [24], which proves that propolis phenolic compounds significantly correlate with antioxidant properties in propolis samples from Mexico. The propolis with the highest TTC is South Sulawesi propolis, which comes from the $G$. incisa species with a content of $0.96 \%$. The type of resin source plant also influences propolis tannin content. South Sulawesi Province is known to have seven types of resin source plants that contain tannin compounds, including durian, cempaka, cacao, pine, randu, resak, and rubber cassava. Tannins have various kinds of biological activities such as antibacterial and antioxidant [25].

The toxicity of propolis can be influenced, one of which is the plant source of resin. According to Mensah et al. [26], some traditional medicine plants can be potentially toxic. It is also supported by Mahani et al. [27] who states that resins from medicinal plants tend to produce propolis with high biological activity and toxicity. Furthermore, from the research, it can be seen that some of the medicinal plants studied had $\mathrm{LC}_{50}$ values $<1000$ [28]
Banten Province, which produces propolis with the highest toxicity, turns out to be of the nine types of resin source plants available, two of which are plants commonly used as medicinal plants, namely, mahogany and mangosteen. Mahogany is a plant commonly used by Indonesians to treat diabetes, while mangosteen is widely used as a medicine for diarrhea, cancer, dysentery, thrush, and kidney $[29,30]$. Research conducted by Handayani et al. [31] shows that the ethanol extract of mahogany seeds is very toxic with an $\mathrm{LC}_{50}$ value of 0.95 and can be an anticancer. Extract of mangosteen leaves has toxic properties with an $\mathrm{LC}_{50}$ value of 30.3 and can be an anticancer [32]. These two studies further reinforce the notion that propolis's toxicity, caused by the type of plant source of resin, and the type of medicinal plant, have a high toxicity.

Another propolis that has high toxicity is propolis, which comes from North Sumatra. This province also has nine types of resin source plants, two of which are medicinal plants, namely kweni and mangosteen. The bark of the kweni plant is commonly used to treat epilepsy. The difference in toxicity of two types of propolis from North Sumatra was caused by differences in the stingless bee species, namely, S. moorei and Tetragonula minangkabau. These species differences can indirectly affect the propolis characteristics produced because each species of bee has unique characteristics. Therefore, although the types of plants available are the same, the plants selected for the propolis resin source can be different.

Based on the Spearman correlation test results, the higher the TFC, the lower the toxicity. This is slightly contrary to various sources that state that flavonoid compounds have a cytotoxic activity increasing propolis toxicity. Vukovic et al. [33] stated that the flavonoids isolated from propolis showed cytotoxic, proapoptotic, and antioxidant abilities. Based on Josipović and Oršolić [34] research regarding the cytotoxic effect of flavonoids on leukemia cells, it was found that the flavonoids quercetin type showed the highest cytotoxic effect, besides caffeic acid, and chrysin also showed high cytotoxic levels. Kaempferol flavonoids are also known to exhibit cytotoxic properties in human pancreatic cells. This kaempferol compound can reduce the viability of pancreatic cancer cells by increasing apoptosis. Quercetin is also known to have potent cytotoxicity because it can induce apoptosis, suppress proliferation, and viability in HepG2 cancer cells [35].

Even so, the resulting correlation data could be due to the flavonoid compounds found in the propolis being tested was dominated by flavonoids with low cytotoxic activity. Therefore, even though the levels of flavonoids are high, the toxicity of these compounds remains low. This statement is supported by Yadegarynia et al. [36], which states that different types of flavonoids have different cytotoxic activities. Tests conducted on breast cancer cells showed that the flavonoids apigenin, luteolin, chrysin, kaempferol, and quercetin had strong cytotoxic activity. In contrast, the flavonoids of the Daidzein, Naringenin, Catechin, and Myricetin types showed weak cytotoxic activity and did not even show the ability to kill cells. Based on research, it is also known that there is not always a correlation between the tested phytochemicals and their level of toxicity [37]. This could be because the compounds that are more toxic to the test organism are other compounds outside the phenolic and tannin groups.

\section{CONCLUSION}

Stingless bee propolis from various provinces in Indonesia contains various phytochemicals and toxicities. This is influenced by the types of bees and the source of resin plants in each province. The phytochemical content of flavonoids in propolis also shows a strong correlation with propolis toxicity.

\section{ACKNOWLEDGMENT}

Special thanks to CV. Nutrima Sehatalami Indonesia which has provided all raw propolis samples. 


\section{AUTHORS CONTRIBUTION}

MM, AS, HH, NN designed the experimental study and carried out the analysis. MM, ZZ, JS, AS, HH, NN contributed in preparing the manuscript and revision. All authors have read and approved the final manuscript.

\section{CONFLICT OF INTEREST}

The authors declared that they have no conflict of interest.

\section{AUTHORS FUNDING}

This research received funding from Directorate General of Higher Education - Indonesian Ministry of Research, Technology and Higher Education.

\section{REFERENCES}

1. Sforcin JM, Bankova V. Propolis: Is there a potential for the development of new drugs? J Ethnopharmacol 2011;133:253-60.

2. Salatnaya H. Produktivitas Lebah Trigona spp. Sebagai Penghasil Propolis pada Perkebunan Pala Monokultur dan Polikultur di Jawa Barat. Bogor, Indonesia: Institut Pertanian Bogor; 2012.

3. Mahani M, Nurhadi B, Subroto E, Herudiyanto M. Bee propolis Trigona spp potential and uniqueness in Indonesia. Proc Univ Malays Teren Annu Sci 2011;2011:1..

4. Anjum SI, Ullah A, Khan KA, Attaullah M, Khan H, Ali H, et al. Composition and functional properties of propolis (bee glue): A review. Saudi J Biol Sci 2019;26:1695-703.

5. Wagh VD. Propolis: A wonder bees product and its pharmacological potentials. Adv Pharmacol Sci 2013;2013:308249.

6. Cauich-Kumul R, Segura Campos MR. Bee propolis: Properties, chemical composition, applications, and potential health effects. In: Bioactive Compounds: Health Benefits and Potential Applications. Amsterdam: Elsevier Inc.; 2018. p. 227-43.

7. Araújo MJ, Mattar NS, Reis AS, Serra IC, Fialho EM, Assunção AK, et al. Pharmacognostic and acute toxicological evaluation of Scaptotrigona aff. postica propolis extract in pre-clinical assays. Nat Prod Res 2011;25:1037-46.

8. Mahani M, Sulaeman A, Anwar F, Damanik MR, Hardinsyah H, Ploeger A. Determination of Indonesian native stingless bee propolis as complementary nutraceutical candidate of anti-tuberculosis drug. Int $\mathrm{J}$ Pharm Pharm Sci 2018;10:15-21.

9. Harborne J, Baxter H. Phytochemical Dictionary: A Handbook of Bioactive Compounds from Plants. Bristol: Taylor and Francis Ltd.; 1993.

10. Khalil MI, Alam N, Moniruzzaman M, Sulaiman SA, Gan SH. Phenolic acid composition and antioxidant properties of Malaysian honeys. J Food Sci 2011;76:921-8.

11. Alotibi IA, Harakeh SM, Al-Mamary M, Mariod AA, Al-Jaouni SK, AlMasaud S, et al. Floral markers and biological activity of Saudi honey. Saudi J Biol Sci 2018;25:1369-74.

12. Supriyanto R. Studi analisis spesiasi ion logam Cr (III) dan Cr (VI) dengan asam tanat dari ekstrak gambir menggunakan spektrometri UVVIS. J Sains MIPA 2011;17:35-42.

13. Ghavamizadeh M, Mirzaei A. Antioxidant activity and hepatoprotective potential of Artemisia aucheri in rat. Indian J Sci Technol 2015;8:56639.

14. Bankova V, Popova M, Trusheva B. Plant sources of propolis: An update from a chemist's point of view. Nat Prod Commun 2006;1:1023-8.

15. Rasmussen C, Cameron SA. Global stingless bee phylogeny supports ancient divergence, vicariance, and long distance dispersal. Biol J Linn Soc 2010;99:206-32

16. Faheem M, Aslam M, Razaq M. Pollination ecology with special reference to insects - a review. J Res Sci 2004;4:395-409.

17. Fawzy A, Al-Deeb M. Biological activity of different botanical origin of propolis. Egypt Acad J Biol Sci 2016;8:1-9.

18. Ramnath S, Venkataramegowda S, Singh C. Chemical composition of bee propolis collected from different regions in India by gcms analysis. Int J Pharmacogn Phytochem 2015;30:1319-28.

19. Cantrell CL, Franzblau SG, Fischer NH. Antimycobacterial plant terpenoids. Planta Med 2001;67:685-94.

20. Hernández Zarate MS, Abraham Juárez MR, Cerón García A, Ozuna López C, Gutiérrez Chávez AJ, Segoviano Garfias JJ, et al. Flavonoids, phenolic content, and antioxidant activity of propolis from various areas of Guanajuato, Mexico. Food Sci Technol 2018;38:210-5.

21. Mello BC, Hubinger MD. Antioxidant activity and polyphenol contents in Brazilian green propolis extracts prepared with the use of ethanol and water as solvents in different $\mathrm{pH}$ values. Int J Food Sci Technol 2012;47:2510-8

22. Bonvehí JS, Gutiérrez AL. Antioxidant activity and total phenolics of propolis from the basque country (Northeastern Spain). J Am Oil Chem Soc 2011;88:1387-95.

23. Nasrulloh N. Pengklasifikasian Propolis Lebah madu Trigona spp. dari Empat Wilayah di Indonesia Dengan Menggunakan Pendekatan Metabolomik Berbasis Ftir. Bogor, Indonesia: Institut Pertanian Bogor; 2013.

24. Alfaridz F, Amalia R. Klasifikasi dan aktivitas farmakologi dari senyawa aktif flavonoid. Farmaka 2018;16:1-9.

25. Kayaputri IL, Sumanti DM, Djali M, Indiarto R, Dewi DL. Kajian fitokimia ekstrak kulit biji kakao (Theobroma cacao L.). Chim Nat Acta 2014;2:83-90.

26. Mensah ML, Komlaga G, Forkuo AD, Firempong C, Dickson RA, Anning KA. Toxicity and safety implications of herbal medicines used in Africa. In: Builders P, editor. Herbal Medicine. London: IntechOpen; 2019.

27. Mahani M, Sulaeman A, Anwar F, Damanik MR, Hardinsyah H, Ploeger A. Efficacy of propolis supplementation to accelerate healing process and body weight recovery of pulmonary tuberculosis patients. J Gizi Pangan 2018;13:1-10.

28. Mwangi GG, Wagacha JM, Nguta JM, Mbaria JM. Brine shrimp cytotoxicity and antimalarial activity of plants traditionally used in treatment of malaria in Msambweni district. Pharm Biol 2015;53:588-93.

29. Fauzia S, Sumekar DW. Efektivitas biji mahoni (Swietenia mahagoni) sebagai pengobatan diabetes melitus. Majority 2016;5:168-72

30. Hidayat S, Napitupulu RM. Kitab Tumbuhan Obat. Jakarta: AGRIFLO; 2015. p. 422.

31. Handayani V, Najib A, Syarif RA, Mahmud A, Hamidu L, Ahmad AR. Uji toksisitas ekstrak etanol terpurifikasi biji mahoni (Switenia mahagoni). J Fitofarm Indones 2019;6:360-2.

32. Pangow ME, Bodhi W, Queljoe E. Skrining fitokimia dan uji toksisitas dari ekstrak etanol daun manggis (Garcinia mangostana L.) dengan metode brine shrimp lethality test. Pharmacon 2018;7:97-209.

33. Vukovic NL, Obradovic AD, Vukic MD, Jovanovic D, Djurdjevic PM. Cytotoxic, proapoptotic and antioxidative potential of flavonoids isolated from propolis against colon (HCT-116) and breast (MDAMB-231) cancer cell lines. Food Res Int 2018;106:71-80.

34. Josipović P, Oršolić N. Cytotoxicity of polyphenolic/flavonoid compounds in a leukaemia cell culture. Arh Hig Rada Toksikol 2008;59:299-308.

35. Perveen $\mathrm{S}, \mathrm{Al}$-Taweel AM. Phenolic compounds from the natural sources and their cytotoxicity. In: Phenolic Compounds: Natural Sources, Importance and Applications. London: IntechOpen Limited; 2017.

36. Yadegarynia S, Pham A, Ng A, Nguyen D, Lialiutska T, Bortolazzo A, et al. Profiling flavonoid cytotoxicity in human breast cancer cell lines: Determination of structure-function relationships. Nat Prod Commun 2012;7:1295-304.

37. Sulaksono FB, Syamsudin. Koreksi kadar flavonoid dan toksisitas dalam ekstrak tempuyung (Sonchus arvensis) dan pegagan (Centella asiatica). Konversi 2012;1:33-42. 